\title{
TRANSGRESSION AND REGRESSION OF THE SOUTH ATLANTIC OCEAN, BRAZILIAN COAST. CASE STUDY: COASTAL PLAIN OF THE PARAÍBA DO SUL RIVER, BRAZIL
}

\author{
Lucio Carramillo CAETANO \\ Departamento de Geociências, UFRRJ \\ carramillo@gmail.com \\ Sueli Yoshinaga PEREIRA \\ Instituto de Geociências, UNICAMP \\ sueliyoshinaga@gmail.com \\ Heitor MOTHÉ FILHO \\ Geociências, UFRRJ \\ heitorfmothe@gmail.com \\ Thiago Andrade de SOUZA \\ Geoquímica Ambiental, UFF \\ thiagoandrade.geologia@gmail.com \\ Sarah G. DUARTE \\ Secretaria de Estado de Educação do RJ \\ sarahpalino@yahoo.com.br \\ Thiago Machado do PINHO \\ Departamento de Geotecnia, USP \\ thiagompinho@usp.br \\ Igor Cristiano SILVA \\ Departamento de Geologia, UFRRJ \\ igorcristiano@hotMyil.com
}

\begin{abstract}
During the 4.6 billion years, the planet Earth has been intensively transforming due to the Magnitude of internal forces of the planet that are responsible for the movement of tectonic plates. In the meantime to this situation countless periods of transgression and regression on the various continents are proven throughout geological time. The present work aims to allow the reader to understand the alternations of this movement of the South Atlantic Ocean on the coast of the northern coast of the Rio de Janeiro state, Brazil, specifically in Atafona, São João da Barra.

The work compiled information on the evolution of the South American continent in the Brazilian territory until reaching in detail the region in focus. In Atafona there are houses and streets destroyed by the invasion of the sea. However, in a detailed analysis, the intention of this work, in fact, the sea has been retreating more than invading, in the last millions of years, there has been more regression than transgression. The simple image allows observing the numerous lines of deposition of marine sediments in Atafona and other parts of the northern coast of the state of Rio de Janeiro, Brazil.
\end{abstract}

Key Words: Coast, Geological Time, Regression, South Atlantic Ocean, Transgression.

\section{Resumo}

Durante 4,6 biliões de anos, o planeta Terra foi-se transformando intensamente através da magnitude de forças internas que são responsáveis pelo movimento das placas tectônicas. Concomitante a essa situação inúmeros períodos de transgressão e regressão nos diversos continentes são comprovados ao longo do tempo geológico. O presente trabalho tem como objetivocompreender as alternâncias dessa movimentação do oceano Atlântico sul na costa do litoral norte do estado do Rio de Janeiro, Brasil, mais especificamente em Atafona, São João da Barra.

O trabalho compilou informações da evolução do continente sul americano no território brasileiro até alcançar em detalhamento a região em foco. Uma visita realizada a Atafona permitiu observar casas e ruas destruídas pela 
invasão do mar. Porém, numa análise mais aprofundada foi constatado que, na verdade, nessa localidade o mar vem recuando mais do que invadindo, ou seja, nesses últimos milhões de anos, tem ocorrido mais regressão do que transgressão. A simples imagem permite observar as inúmeras linhas de deposição de sedimentos marinhos tanto em Atafona com em outras partes do litoral norte do estado do Rio de Janeiro, Brasil.

Palavras chave: Costa, Oceano Atlântico Sul, Regressão,Tempo Geológico, Transgressão.

\section{Introduction}

Streets and houses near the Atafona beach in the coastal plain of the Paraíba do Sul river in the northern state of Rio de Janeiro, Brazil, are regularly destroyed by the advance of the Atlantic Ocean. This situation causes not only the destruction of commercial and private properties, as well as squares and access roads, and it is also responsible for damages to the public and private sector in their real estate investments and infrastructure, literally carried by the sea (figure 1).

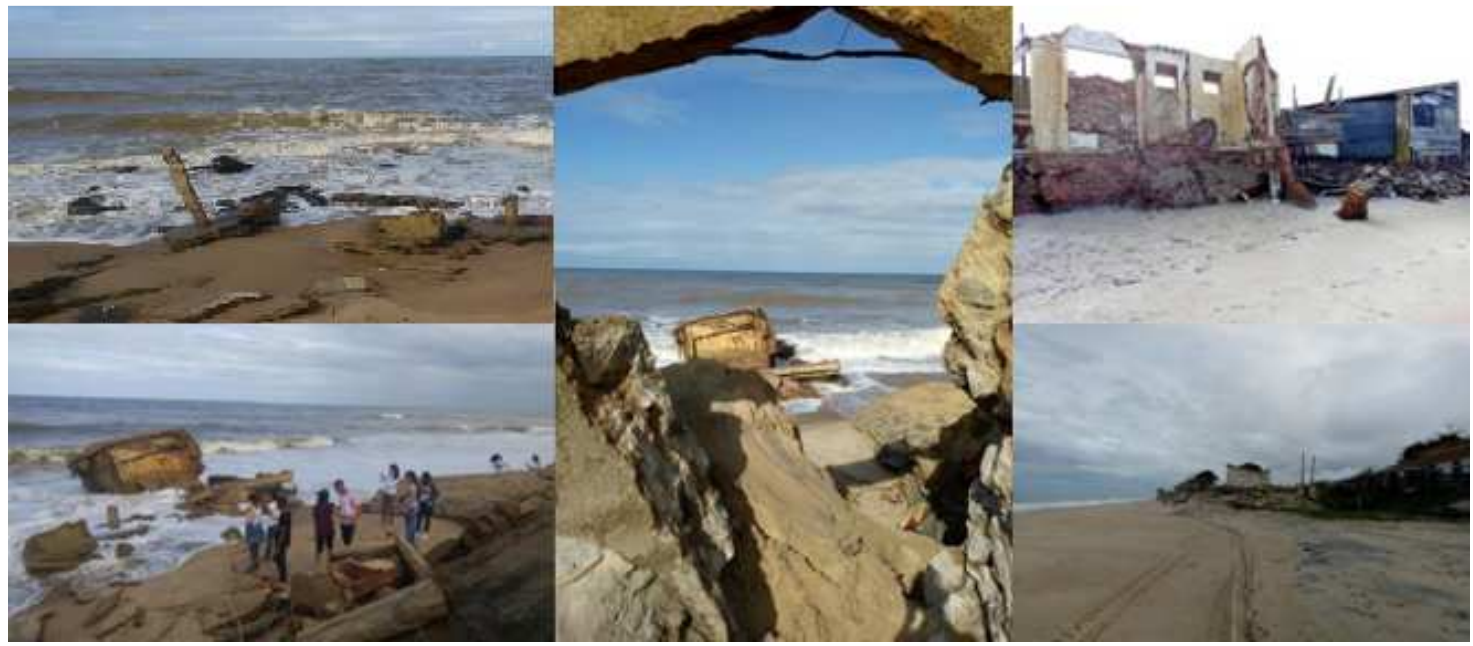

Figure 1 - Damage caused by marine transgression in Atafona, RJ, Brazil (Caetano, 2018).

At first glance, and taking into account only the possible environmental changes brought about by Man throughout his life on planet Earth, one could imagine that the transgression in that locality was directly linked to the production of atmospheric pollutants that could provoke the global warming and, consequently, rising sea levels.

However, there is a fundamental question that must be considered, the Geological Time (figure 2). The knowledge of the geological time scale obliges us to take into account at least the 4.6 billion years of the existence of the planet Earth.

Thus, this work aims to clarify, based on the geological time scale, the transgressions and regressions that occur in the northern region of the state of Rio de Janeiro, Brazil. 


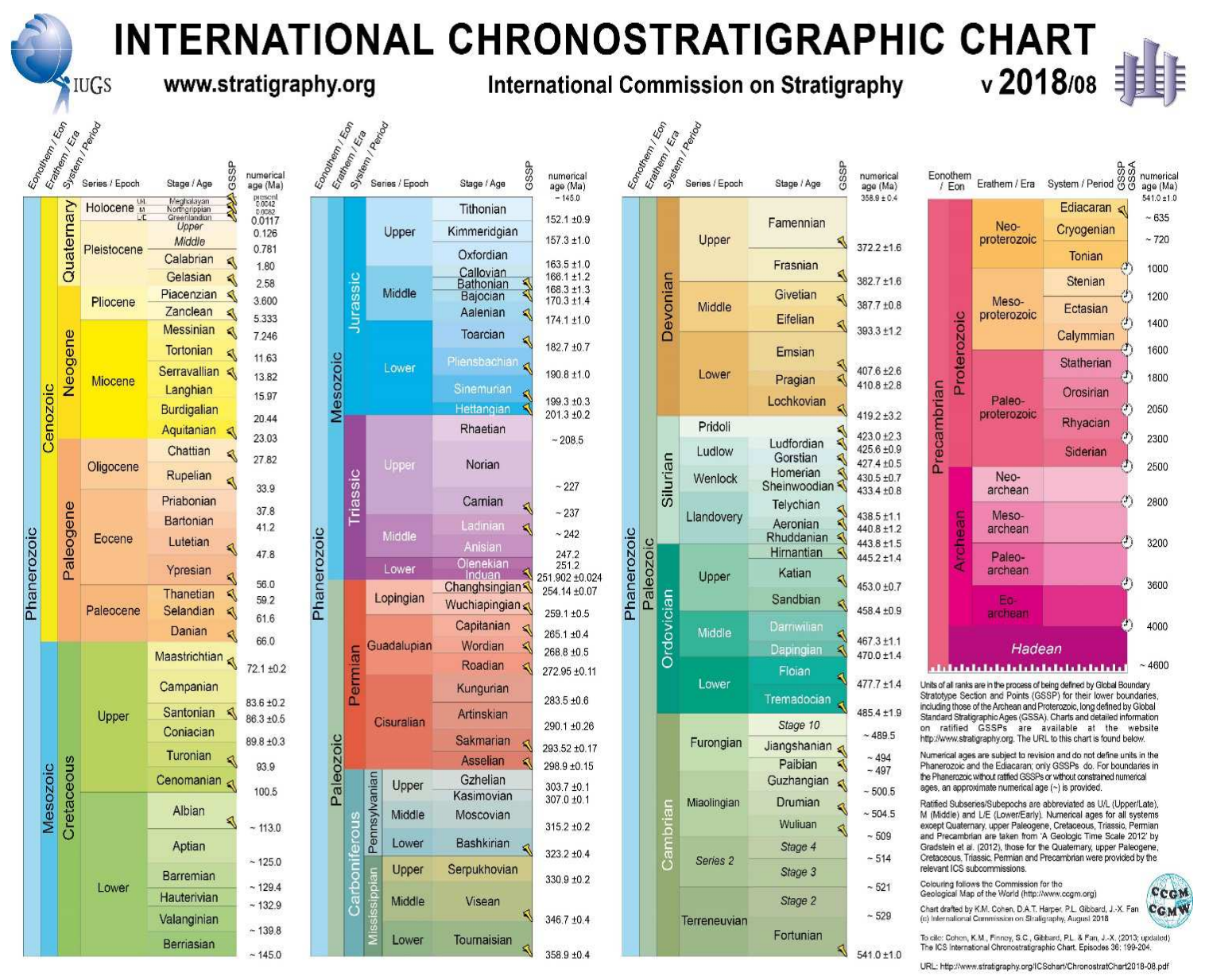

Figure 2 - Geological Time Chart (http://www.stratigraphy.org/index.php/ics-chart-timescale, accessed in 12/05/2019).

\section{The Geological Time}

Depending on the activities carried out by each one of us in our daily life, these are linked to our professions or even to our leisure moments, the notion of time is spontaneously related to our tasks.

It is natural to imagine that professionals in the field of physics and chemistry, for example, may more easily perceive situations occurring in fractions of seconds such as the separation of an atom's nucleus and chemical reactions, unlike professionals in the fields of social sciences, geography, biology and engineering, among others that will have a sharp perception for days, months, years, decades or even centuries through the evolution of human species, animals, plants, as well as some climatic phenomena. On the other hand, professionals in the field of geology, as well as those in the field of astronomy, will have a greater perception of time in such a way as to reach the order of billions of years, when analyzing the formation of the universe, the formation of mountains, the formation and movement of continents, marine transgressions and regressions, erosion and weathering, for example. 
There is, however, a rather simplified way for anyone, regardless of this area of expertise, to know and even follow the evolution of our Planet from the moment of its formation, 4.6 billion years ago, to this day. The Geological Time Scale (figure 2) enables both geologists and paleontologists, as well as society in general, to acquire knowledge of events occurring at various intervals in the formation, transformation, and evolution of planet Earth.

For this, the study and knowledge of the rocks will be fundamental. The rocks formed in the past and preserved from erosion serve as a memory of the Earth, recording geological events such as glaciations that lasted many thousands or millions of years. Rock strata and fossils determine the relative age of sedimentary rock layers and radioactive decay determines the absolute age of the rock, identifying the different ages of evolution of the planet Earth (PRESS, 2006).

The Geological Time Scale is divided into Eon, Era, Period, Epoch, and Age (International Commission on Stratigraphy, 2018 v.8). This Scale divides geological time into two Eons, they are: Pre-Cambrian and Phanerozoic. The earliest geological Eon is the Precambrian, beginning 4.6 billion years ago with Hadean, passing through the Archaean (from 4 Gy to $2.5 \mathrm{~Gy}$ ago) to the Neoproterozoic (2.5 Gy to $541 \mathrm{My}$ ). The most common rock units in the Archean are the metamorphic complexes consisting of gneisses and granitoids and subordinate metavulcanic sedimentary sequences (WINCANDER, 2009). During the Archean, when there was more heat on the Planet, the movement of tectonic plates was faster than at present. In the Proterozoic (from $2.5 \mathrm{~Gy}$ to $541 \mathrm{My}$ ), was a time of deposition of iron formations flocks, red beds, sandstones, siltstones, carbonates, shales and sedimentary rocks glacial indicating glacial episodes. During the Proterozoic occurred important orogens with a great continental growth. It was in this Éon that Laurentia was formed (WINCANDER, 2009).

The Phanerozoic Aeon begins 541 million years ago and continues to this day. The Phanerozoic is divided into three great Eras: Paleozoic (from $541 \mathrm{My}$ to $251 \mathrm{My}$ ), Mesozoic (from 251 My to $66 \mathrm{My}$ ) and Cenozoic (from 66 My to the present day). Each of these Eras is divided in Periods. The Paleozoic, for example, is divided between the Periods: Cambrian (from $541 \mathrm{My}$ to $485 \mathrm{My}$ ), Ordovician (from $485 \mathrm{My}$ to $443 \mathrm{My}$ ), Silurian (from $443 \mathrm{My}$ to $419 \mathrm{My}$ ), Devonian (from $419 \mathrm{My}$ to 358 My), Carboniferous (from $358 \mathrm{My}$ to $298 \mathrm{My}$ ) and Permian (from $298 \mathrm{My}$ to $251 \mathrm{My}$ ). The Mesozoic is distributed in 3 Periods, they are: Triassic (from 251 My to $201 \mathrm{My}$ ), Jurassic (from $201 \mathrm{My}$ to $145 \mathrm{My}$ ) and Cretaceous (from $145 \mathrm{My}$ to $66 \mathrm{My}$ ). Finally, the last Era, the Cenozoic, is divided into three periods: Paleogene (from $66 \mathrm{My}$ to $23 \mathrm{My}$ ), Neogene (from $23 \mathrm{My}$ to $2.58 \mathrm{My}$ ) and the Quaternary from 2.58 My to the present day. Still within the geological time scale, Periods are divided into Epochs. In order to give the present work more objectivity in relation to the most recent transgressions and regressions in the study area, it was decided to deepen the information from the Neogene Period, particularly the Pliocene Age, until the Holocene Age (or Recent) of the Quaternary Period. However, partial information will be given on the whole evolutionary process of the South American continent, especially in the present Brazilian territory, regarding transgression and regression during the Phanerozoic Era, beginning with the Paleozoic, followed by the Mesozoic and closing in the Cenozoic, including through images, of what happens at the present moment. 


\subsection{From the Cambrian ( $541 \mathrm{My}$ ) to the Ordovician (443 My)}

In Cambrian the existing continents were: Baltica, China, Gondwana (composed of the South American continent, African, Antarctic, Australian, Indian, part of the Middle East and South of Europe, Kazakhstan, Laurentia (composed by much of North America, Greenland, Ireland, Scotland and part of Russia) and Siberia, besides these, numerous micro continents and island arches associated with micro plates also made up the planet Earth. During the Cambrian part of Laurentia, Baltic, Siberia, Kazakhstan and China, were covered by shallow seas (marine transgression), while in Gondwana, plateaus were present (WINCANDER, 2009),

Between the Cambrian and Devonian periods, fault zones on the South American continent were filled by sediments forming the sedimentary basins of what would become part of the Brazilian territory. Even today, sedimentary basins that have not been eroded are exposed in several parts of the Brazilian territory. Even without the presence of typically Marine fossils, they have layers indicative of marine deposition. In the basins, now called the basins of Acre, Solimões, Amazonas, Alto Tapajós, Parecis, Paraná, Parnaíba, among others of smaller extent where fossils are found, are also found epicontinental seas that in the Paleozoic flood large areas that, however, due to erosion at its edges, its limits cannot be precisely established. The sediments deposited during the Paleozoic transgressions and regressions are located mainly in the larger basins, revealing extensive transgressions in the Paleozoic (ALMEIDA, 2004).

\subsection{From the end of the Ordovician ( $443 \mathrm{My}$ ) to the end of the Silurian ( $410 \mathrm{My}$ )}

Between the Ordovician and Silurian periods, the sea invasion occurred in the Amazon basin located in the northern region of Brazil (PETRI, 1983, ALMEIDA, 2004), where a neritic environment alternates with typically deltaic, coastal, glacial and glacial marine sediments (GRAHN, 1992, ALMEIDA, 2004). There is also evidence of Marine deposits occurring between the Ordovician and the Silurian in the Upper Tapajós, Parnaíba and Paraná basins, which also presents glacial evidence. During these periods a peak of marine transgression occurred in the central and northern area of this basin. There are numerous indications of glacial actions and indications that the sea was cold (ALMEIDA, 2004).

\subsection{From the beginning of the Devonian ( $410 \mathrm{My})$ to the end of the Carboniferous (298 My)}

At the beginning of the Devonian period (between $410 \mathrm{My}$ and $303 \mathrm{My}$ ), an orogenic cycle took place causing epirogenetic lifting that reflected in the Marine regression, causing erosion in part of the sediments that had been deposited by the sea. The transgressive/regressive cycle during the Devonian caused the transgression of sediments to the same area that had eroded during the marine regression. The transgression occurred at the beginning of the Devonian, extending to the Amazon 
basin (Figure 3) with deposition in the neritic environment, sea glacier, deltaic fluvial, lagoons and restricted sea, regressing at the end of the Period (BLESS, 1986, CUNHA, 1994, ALMEIDA, 2004). In the Devonian, marine flood occurred in the Parnaiba Basin (Figure 3). Part of the sediments typical of marine environments, deltaic, fluvial and tidal plains were removed during the regression at the beginning of the Carboniferous (GOES, 1994, ALMEIDA, 2004). Thus, during the Devonian several transgressions occurred depositing sediments that, despite the marine regression, were partially protected by allowing a more appropriate reading of the transgression and regression phases along the geological time (between $410 \mathrm{My}$ and $358 \mathrm{My}$ ). Even when, through the orogeny occurred during the Carboniferous (between $358 \mathrm{My}$ and $298 \mathrm{My}$ ) that caused the withdrawal (regression) of the sea leaving the deposited sediments previously exposed to erosion until a new transgression occurred more towards the end of the Carboniferous (between $323 \mathrm{My}$ and $298 \mathrm{My}$ ). It is interesting to note that it was in the Upper Devonian (between $382 \mathrm{My}$ and $358 \mathrm{My}$ ) that it reached the Maximum of flood (figure 4) during the whole Period (MELLO, 1989, ALMEIDA, 2004). It is believed that the proto pacific has come to cover $1 / 4$ of the entire Brazilian territory (PETRI, 1983, ALMEIDA, 2004). During the Devonian and the Carboniferous the evolution of the Marine basins occurred due to the sedimentary siltation, epirogenic movements and eustatic fluctuation. It was during the Devonian and Carboniferous periods that coastal, fluvial, deltaic, lagoon, tidal plains, periglacial and glacial deposits were found, evidencing the occurrence of sea retreat and glaciation in the basins that today are located in northern Brazil (ALMEIDA, 2004).
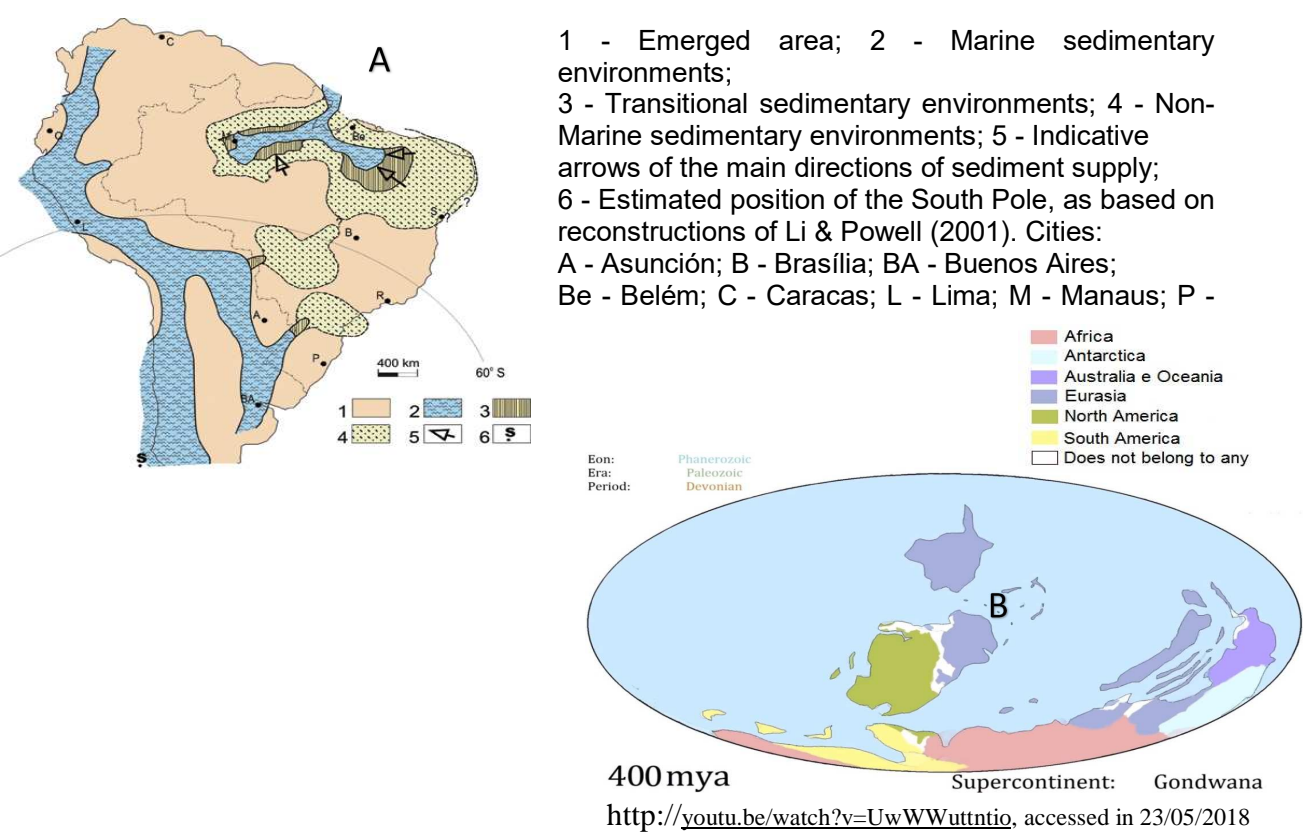

Figure 3 - A: Situation of Brazil during the Devonian. B: Approximate location of Brazil 400 mya. 


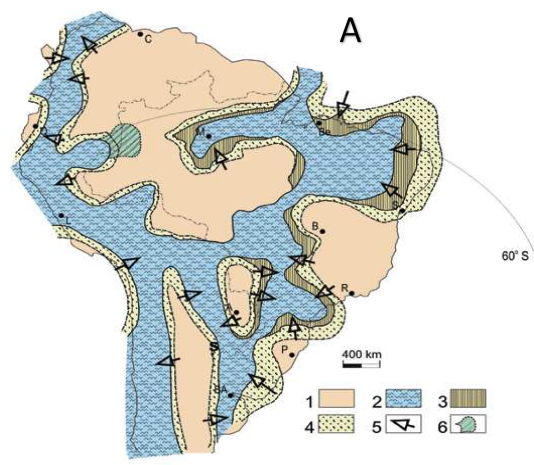

\begin{abstract}
Mesodevonian flooding (Eifelian/Givetian) in Brazil (approx. 380 My), based on Melo, 1989 apub ALMEIDA, 2004.
\end{abstract}

Mesodevoniana flood (Eifeliano/Givetiano) no Brasil (aprox. $380 \mathrm{My}$ ), based in Melo ,1989 apud ALMEIDA, 2004.

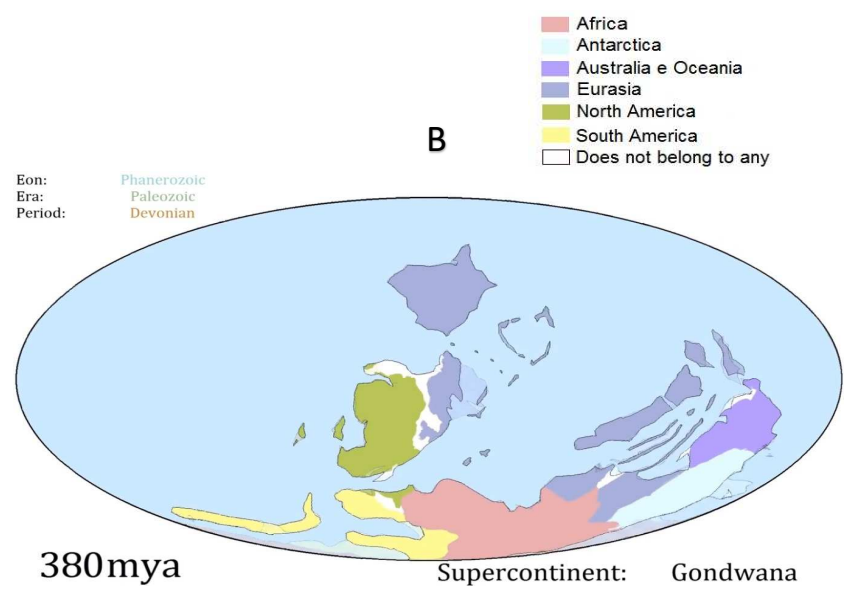

https://www.youtube.com/watch?v=UwWWuttntio, accessed in 23/05/2018

Figure 4 - A: Brazilian territory in its Maximum flood. B: Approximate location of Brazil 380 mya.

\title{
2.4. End of the Paleozoic Era, from the end of the Carboniferous (298 My) to the end of the Permian (251 My)
}

At the end of the Carboniferous occurs the marine transgression forming evaporitous carbonaceous deposits. This transgression had been preceded by a fluvial deltaic sedimentation to wind sedimentation (LEMOS, 1989; ALTINER, 1991, EIRAS, 1994, ALMEIDA, 2004). At the beginning of the Permian, caused by an orogenesis, there was a lacustrine fluvial regression sequence, followed by a long erosive phase with an estimated duration of 170 million years, that is, it remained until the end of Cretaceous, or up to 66 million years ago (ALMEIDA, 2004). In the Amazon basin, the discovery of several fossils of various marine organisms (cephalopods, braqueopods, equinoids, among others) indicating that the sediments forming this Basin are of Neocarboniferous origin. With the regression, evaporites were deposited still in the Carboniferous. Already with the Permian orogenesis, continental sedimentation occurred. The same occurred in the Parnaíba basin, where fossils of fish and other Marine animals are also found, suggest the occurrence of a marine transgression followed by a regression in the Permian where fossils characteristic of shallow marine environments, deltas, lakes and typical vegetation and terrestrial environment (ALMEIDA, 2004).

\subsection{During the Mesozoic, from the beginning of the Triassic ( $251 \mathrm{My})$, Jurassic (201.3 My to $145 \mathrm{My}$ ) to the end of the Cretaceous (66 My)}

Still between the Cambrian and Permian periods, the Pangeia (Figure 5) was located in a large thermal mantle (Anderson, 1992, VIEIRA, 1989, Almeida, 2004), which caused a regression of the sea. Tectonic events and magmatism caused the rupture of the continent and the emergence of 
smaller continents and new seas as it is today. Part of what would be the Brazilian territory remained until the Eocretáceo (145 My to $100 \mathrm{My}$ ). Already situating itself in an arid zone propitiating the development of the Botucatu desert that today is part of the extensive aquifer Guarani one of the largest reservoirs of groundwater of the planet. During the fragmentation of the Pangeia, which began around $237 \mathrm{My}$ during the Triassic period, it began soon after the drift of the continents around $175 \mathrm{My}$ ago, already the Jurassic period. The Atlantic Ocean widens in such a way that the North American continents, part of the African continent and South America moved away (ALMEIDA, 2004).

Between the Triassic and the Cretaceous intense tectonic activities with faults being reactivated, the appearance of numerous fractures, basaltic lava effusion and alkaline magmatism occurred in the South American platform region (ALMEIDA, 2004). It was during the Mesozoic that the South American and African continents moved away and, despite the constant and uninterrupted movement, they are disposed with contours similar to the current ones. Figure 6 represents the appearance of the beginning of the separation between the Brazilian and African territories, as well as the current aspect and the forecast for 46 million years from now. Also in the Cretaceous, deposits of evaporites in much of the present Brazilian coast from the state of Alagoas in the Brazilian northeast to the city of Santos in the state of São Paulo, in the southeast of Brazil (ASMUS, 1980, ALMEIDA, 2004). In the Cretaceous, also deposition of carbonate rocks occurred and closer to the equator there were accumulations of continental and marine sediments (ALMEIDA, 2004).

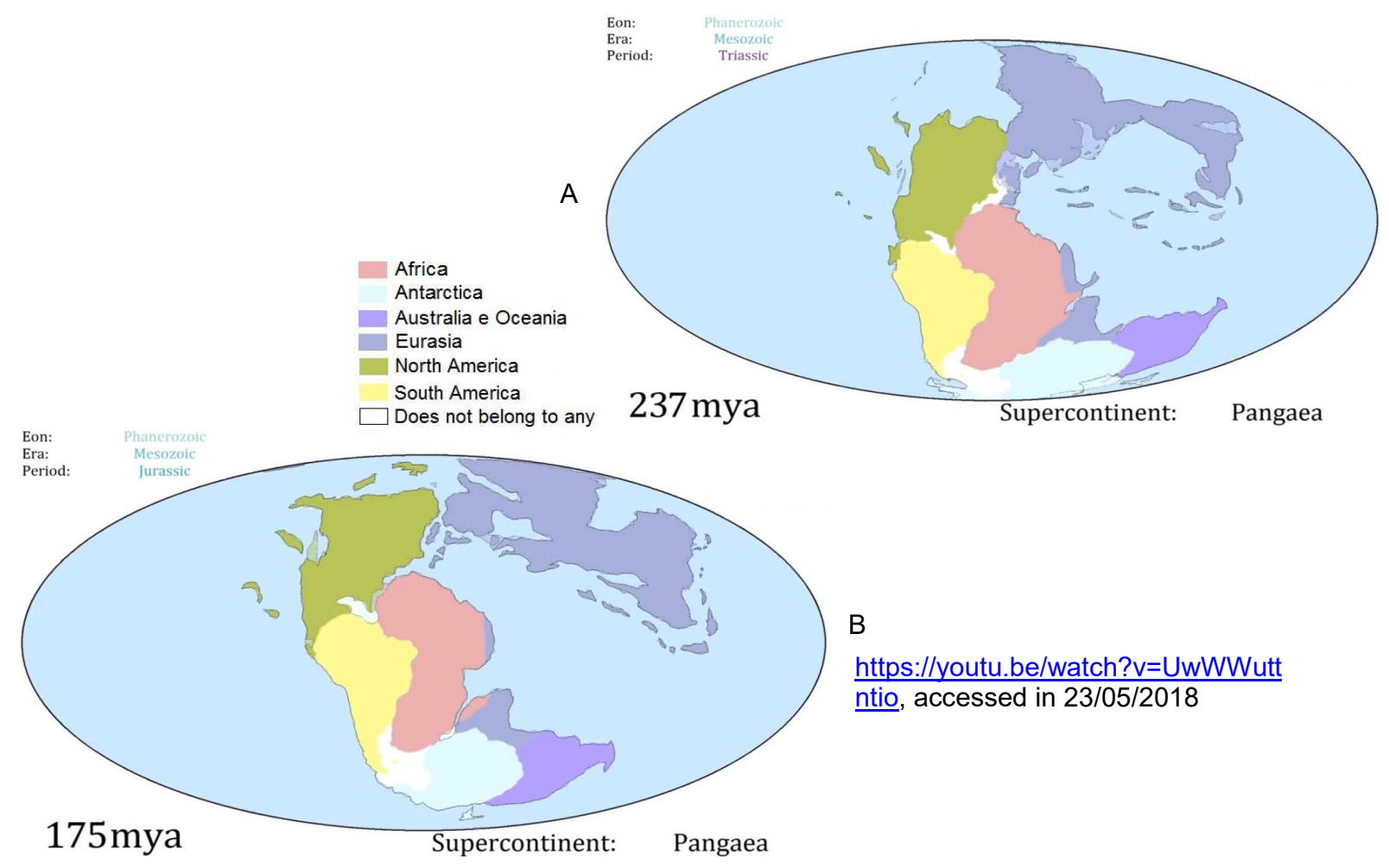

Figure 5 - Brazilian territory united to the African continent (Pangea). A: 237 mya; B: 175 mya. 


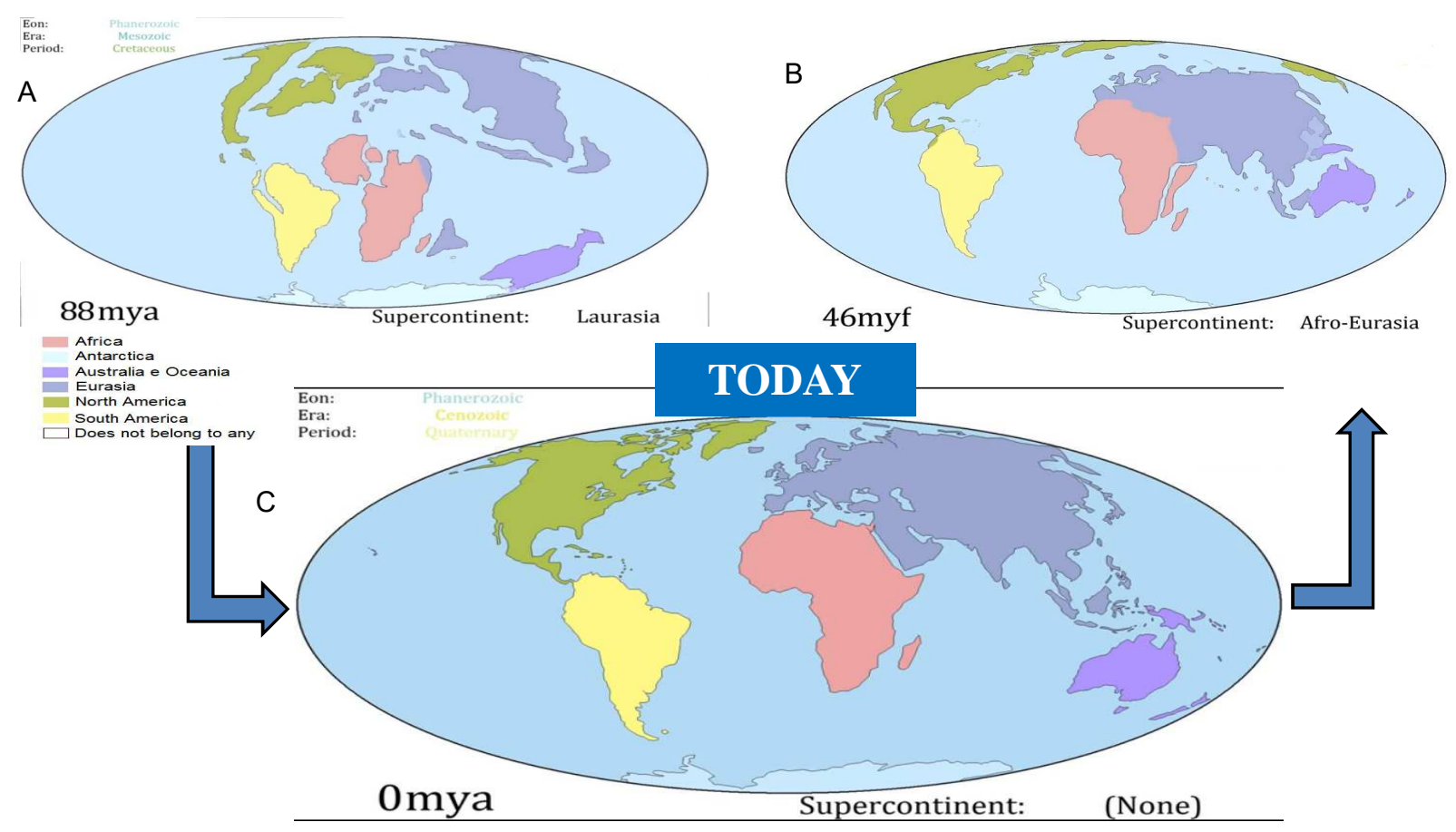

https://youtu.be/watch?v=UwWWuttntio, accessed in 23/05/2018

Figure 6-A: Beginning the separation of the Brazilian territory from the continent African, B: current situation and C: hence 46 Myf.

\subsection{During the Cenozoic, from the Paleogene (66 My) to the Quaternary (days of today)}

During the Cenozoic Era, on the northern Brazilian coast, a sedimentation caused by ocean transgression occurred (MILANI, 2000, ALMEIDA, 2004). Marine transgressions occurred in the northern Brazilian coast at various times of the Paleogene Period, such as: Paleocene (from 66 My to $56 \mathrm{My}$ ) and Eocene (from $56 \mathrm{My}$ and $33 \mathrm{My}$ ). Transgressions are also identified in the Neogene Period, such as Miocene (from 23 My to $5.3 \mathrm{My}$ ) and Pliocene (from 5.3 My to 2.58 My), as evidenced by the deposition of typical marine sediments of the shallow sea (ALMEIDA, 2004). Although the entire Brazilian coast suffered transgressions and regressions during the Cenozoic Era, it was during the Quaternary Period that the sedimentation of the great deltaic plain of the Paraíba do Sul river occurred, representing the emergent part of the deltaic system with a great accumulation of marine sediments (RANGEL, 1994, ALMEIDA, 2004).

It is in this Era that it has been possible to collect the largest number of data to prove the transgressions and regressions that occur in the Brazilian coast, specifically in the north coast of the state of Rio de Janeiro, focus of this work (Figure 7). For this reason, an item will only be dedicated to the Quaternary Period (from 2.58 My to the present day) where it is possible to even visualize the 
transgressive and regressive processes especially in the study area. In this way, the evolution of these processes is described below.

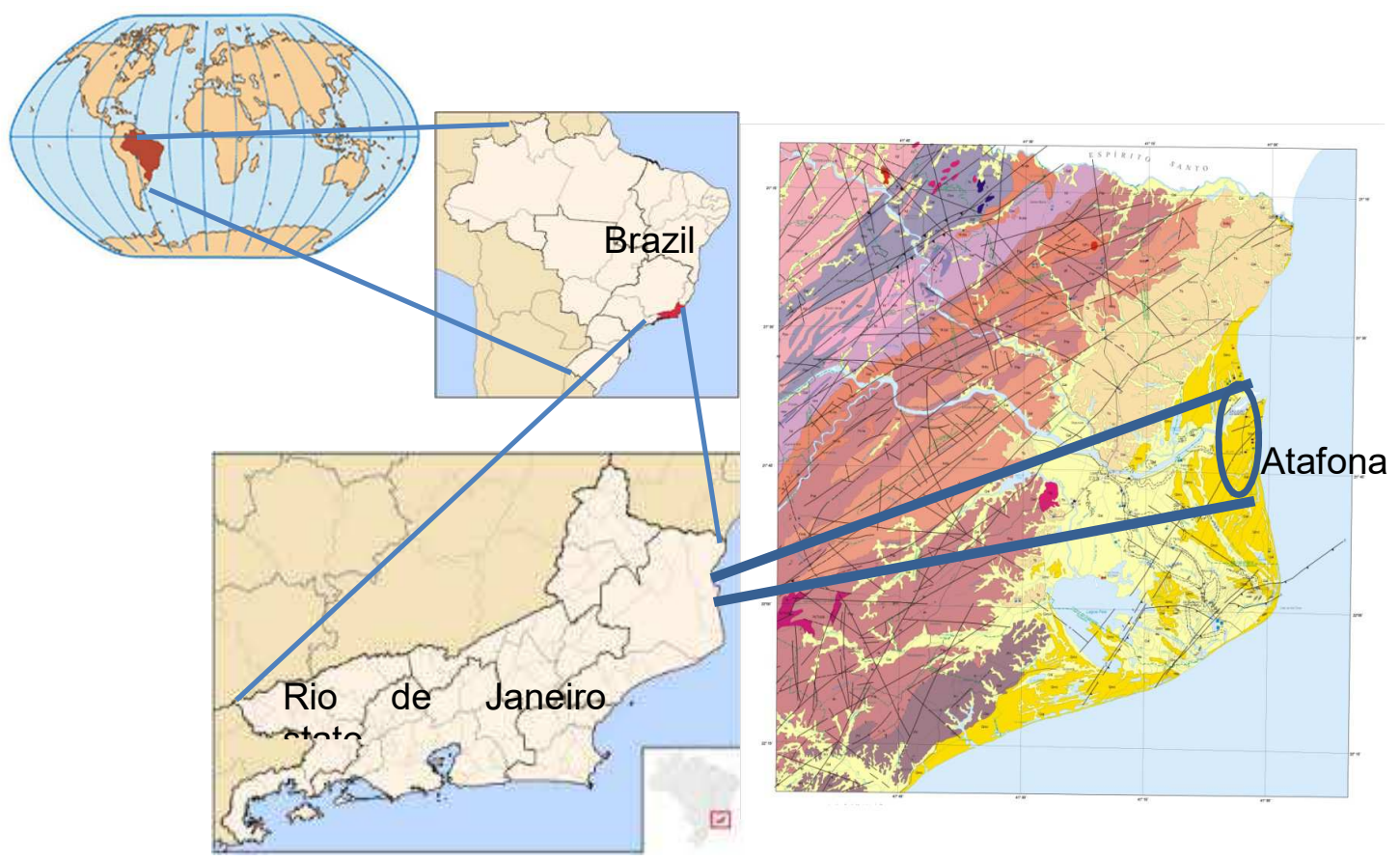

Figure 7 - Location of the study area of Atafona, RJ, Brazil.

In this age, too, it has been possible to collect information that demonstrates the great force exerted by the internal dynamics of the planet, when it can be observed at the very moment when the African continent opens in Kenya (figure 8a). This phenomenon has also been occurring in Iceland and Icelandic territory has also been divided (figure 8b). Apart from this, magmatic processes through intense volcanism occurring in the islands of Hawaii (figure 8c) in the United States of North America, extending the perimeter of some islands or even helping in the formation of new islands. In addition to Hawaii, other localities such as Chimaltenango, Escuintla and Sacatepéquez in Guatemala have been suffering the effects of volcanic. Tsunamis occurring in various parts of the planet but one of the last occurring in Japan caused by earthquakes on the high seas, as well as the earthquake that occurred in Nepal (Figure 8d) in 2015, are natural geological processes that, like the transgression and marine regression that has been occurring since the beginning of the formation of the planet, cause morphological and structural changes that, when in the presence of Man, usually cause apprehension, insecurity and panic, because they are totally beyond of human control. 


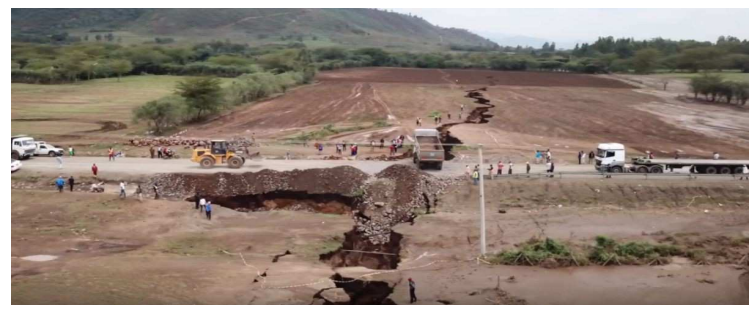

(a) https://revistagalileu.globo.com/Ciencia/no ticia/2018/04/rachadura-gigante-noquenia-mostra-que-africa-se-dividira-emduas.html accessed in 23/05/2018

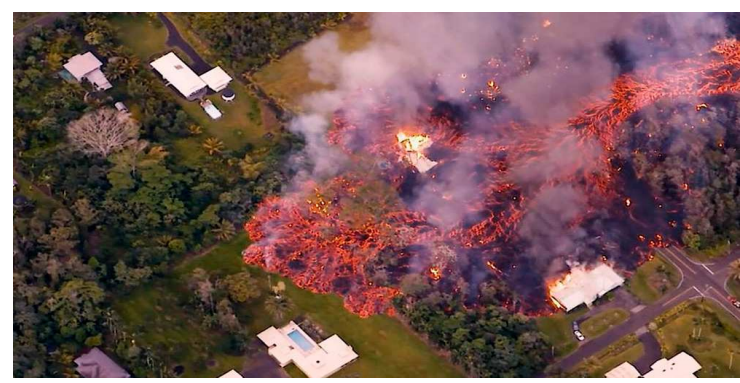

(c) https://mormonsud.net/noticias/mormonsno-havai-vulcao-kilauea/ accessed in $23 / 05 / 2018$

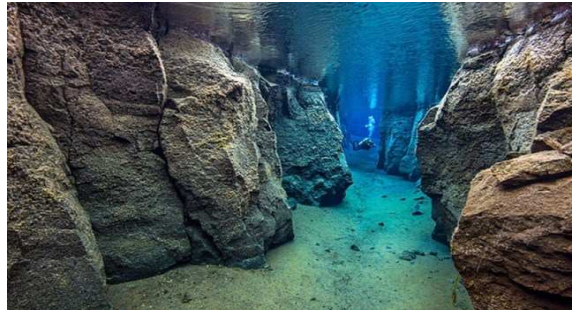

(b) https://www.megacurioso.com.br/lugaressurpreendentes/42947-sabia-que-e-possivelmergulhar-entre-duas-placas-tectonicas-naislandia.htm accessed in 23/05/2018

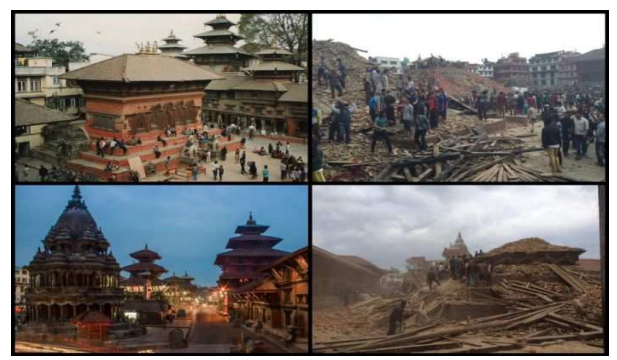

(d) http://resumodanet.com/2015/04/fotosde-antes-e-depois-do-terremoto-nonepal.html accessed in 23/05/2018

Figure 8 - Changes in the planet caused by the Earth's internal dynamics

Recent status of territories: (a) Kenya, Africa; (b) of Iceland; (c) from Hawaii and (d) from Nepal.

\section{Transgressions and Regressions of the South Atlantic Ocean on the North Coast of the State of Rio de Janeiro, Brazil, in the Cenozoic between the Pliocene (5.3 My) and the Holocene or Recent (Quaternary)}

In this section, the phases of transgression and regression occurring, and still occurring, on the northern coast of the state of Rio de Janeiro (figure 9) are described in more detail.

According to MARTIN, 1997 (CAETANO, 2000), between the Pliocene and the Quaternary, there were 7 stages of transgression and regression.

Stage 1: Probably during Pliocene (between 5,3 $\mathrm{My}$ and 2,5 My), in a phase of marine regression, in a semi-arid climate and subject to sporadic and torrential rains, the sedimentation of the Barreiras formation occurred in large bands of coalescent alluvial fans (MARTIN, 1997);

Stage 2: Humid climate interrupting the deposition of the Barreiras formation (MaRTIN, 1997). Next, during probably the Pleistocene $(2.5 \mathrm{My}$ to $0.01 \mathrm{My}$ ) there must have been a marine transgression. The outer part of the Barreiras Formation was eroded forming a line of cliffs;

Stage 3: In a marine regression phase, the climate must have returned to the semiarid zone, allowing a new sedimentation of continental deposits made up of coalescing alluvial fans at the foot of escarpments carved in the sediments of the Barreiras formation (MARTIN, 1997); 
Stage 4: In the Middle Pleistocene, around 123,000 years BP (Before Present) when the sea, during the penultimate transgression, eroded all or part of the continental deposits of the previous stage, the low rivers were drowned giving rise to estuaries and lagoons;

Stage 5: Phase in which the sandy terraces formed by progradant beach ridges were constructed during the regression in the Middle Pleistocene to the Superior;

Stage 6: During the Holocene (from 11,000 years to today) at most in the transgression of about 5,100 years BP, the sea must have eroded all or part of Pleistocene marine terraces. The sea invasion of the Pleistocene Marine terraces and the sediments of the Barreiras

Stage 7: Phase relative to the lowering of the sea from 5,100 years BP that caused the transformation of the lagoons into freshwater lakes and, finally, into marshes. This stage is also related to small sea level fluctuations that were very important for the development of the newest portions of the coastal plains located in the mouths of the Paraiba do Sul river in the state of Rio de Janeiro and the Doce river in the state of Espirito Santo. It is possible to check several houses and streets destroyed by the advance of the sea just walking the streets of the city of Atafona going towards the beach. In the same way, one can observe the destruction caused by the most recent minor transgressions (figure 1). On the other hand, it is also possible to observe large extensions of marine deposits on the rim that clearly demonstrate seaward retreat activities (figure 9).

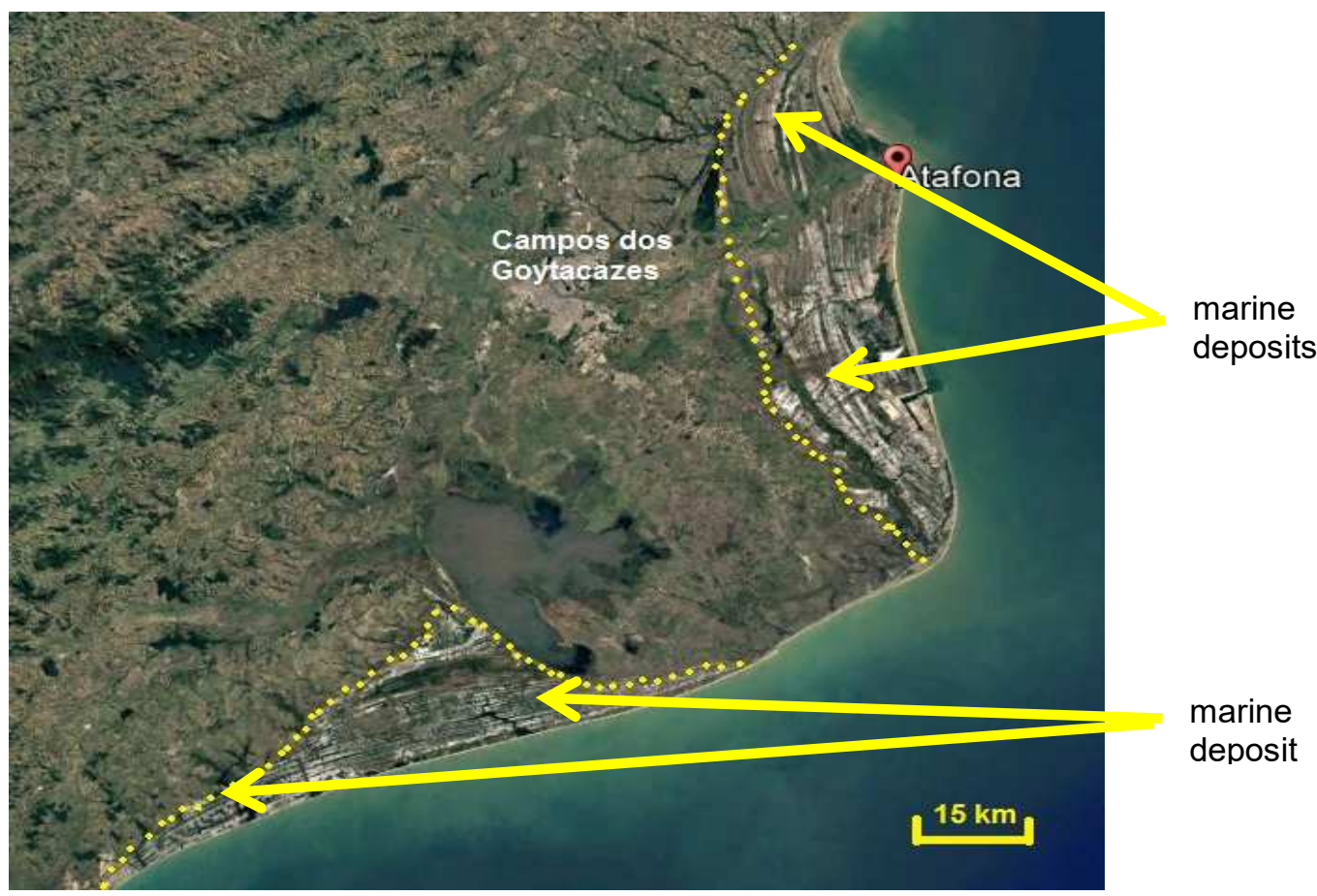

Figure 9 - View of marine deposits from Cenozoic on the northern coast of the State of Rio de Janeiro (Brazil) (Google Earth, 2018).

\section{Conclusions}

The planet Earth is being formed 4.6 billion years ago. It should be emphasized that "it is being formed" because, at this very moment, changes are occurring. Some coasts are being flooded by the 
sea, others are being enlarged by the retreat of the sea, regions are having their areas reduced by the clash between continental plates (as is the case in Nepal), others are being enlarged by the expelled volcanic magmatism giving them new areas (as is the case in Hawaii), and there are still those that suffer only a few changes that do not necessarily imply the enlargement or diminution of their territories, as has happened in Iceland and Africa, through the rupture of the plates and openings with the distance between them and the volcanism in Guatemala that, for the moment, has caused only a change in the local morphology.

Thus the cyclical alterations of the continents that occurred uninterruptedly aggressions provoked by the internal dynamics of the Earth (earthquakes and magmatism) as well as by transgressions and regressions usually provoked, also, by the different phases of the evolution of the planet through the movement of the tectonic plates and the driving force fundamental for this movement attributed to thermal convection of the mantle, That is, the plates of the lithosphere move on the surface of the planet being dragged by the convection of the mantle, which consequently cause earthquakes, volcanism beyond the action of erosion. Figure 10 shows the division of the tectonic plates in the Earth. This whole system of natural alterations of the Planet allows the concentration of minerals with economic viability, formation of beautiful landscapes with the creation of geological monuments as well as unpleasant and worrying situations such as: destruction of houses, streets (figure 1), highways, bridges, viaducts which often cause accidents, deaths and dozens or hundreds of homeless. Figure 11 shows a hydrogeological profile of the Barreiras aquifer in Atafona, Rio de Janeiro, Brazil.

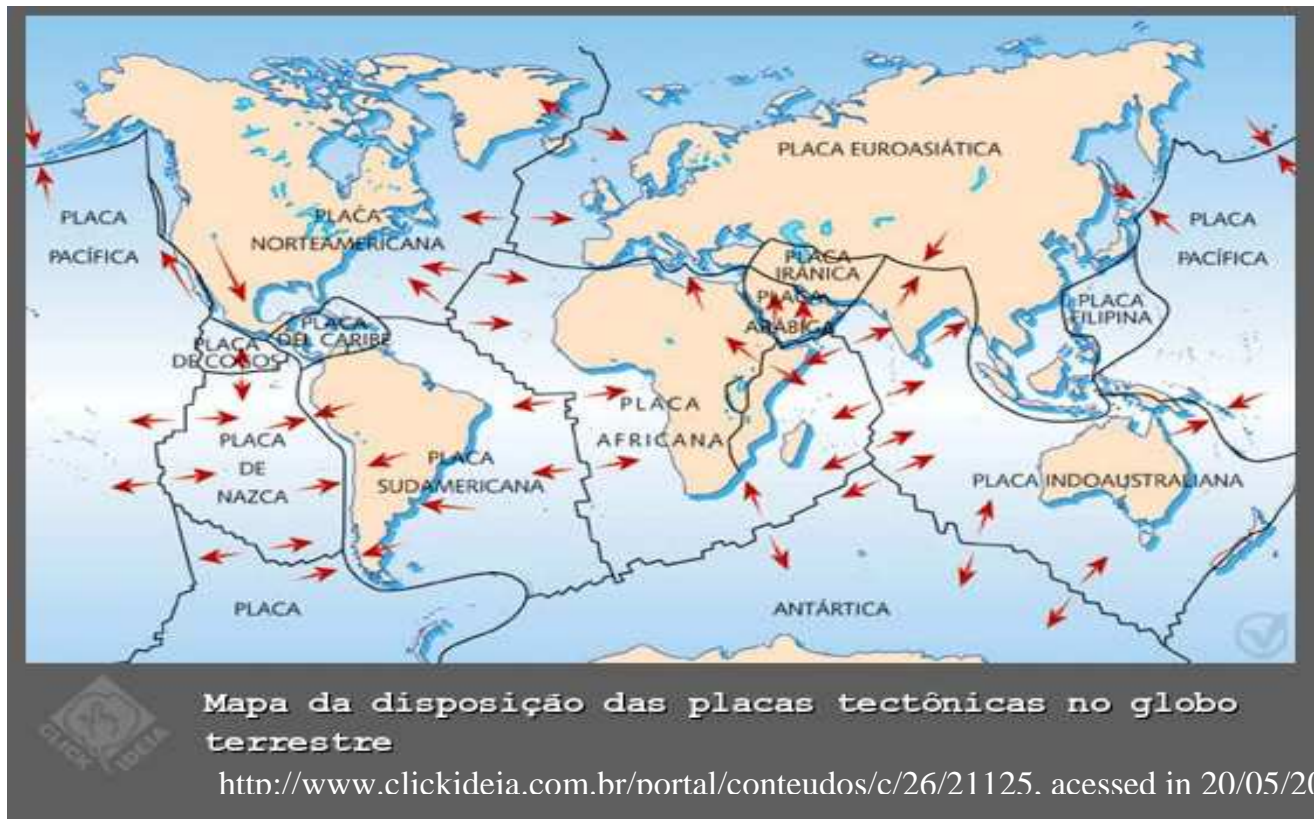

Figure 10 - Map of the Layout of Tectonic Plates in the Terrestrial Globe

Perhaps the greatest importance of this work is to allow the reader to observe that long before the human presence on Earth, the Planet alone made its own history by the evolutionary 
transformations that, in a way, can be observed from 4.6 billion of years in a constant process of alterations (construction and destruction) of environments, through the own transgressions and marine regressions that has been offering us, throughout the geological time, varied regions of aspects so own and differentiated.

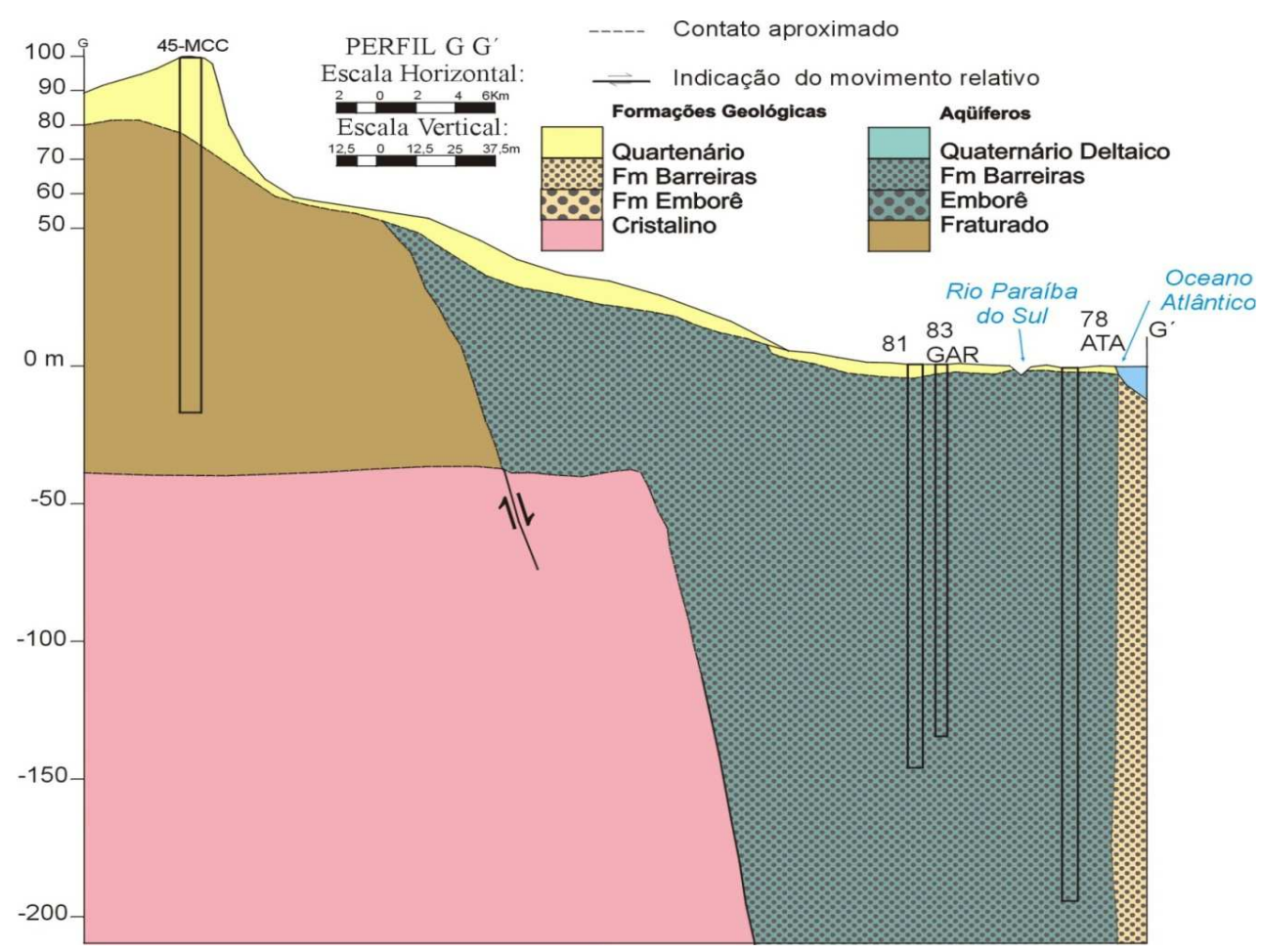

Figure 11 - Hydrogeological profile showing the aquifer Barreiras, Atafona, RJ, Brazil (CAETANO, 2000).

\section{Bibliography}

ALMEIDA, F.F.M. \& CARNEIRO, C.D.R. (2004), Inundações Marinhas Fanerozoicas no Brasil e Recursos Minerais Associados. In BECA (Ed.), Geologia do Continente Sul Americano: Evolução da Obra de Fernando Flávio Marques de Almeida (pp 43 a 58). São Paulo.

ALTINER, D. \& SALVINE, R. (1191), Pennsylvanian foraminífera and carbonate microfacies from the Amazonian and Solimões basins: bioestrarigraphie, paleocologic and paleogeographic results. Rio de Janeiro, PETROBRÁS. (rel. int.).

ANDERSON, D.L., TANIMOTO, T. \& ZHANG, Y.S. (1992). Plate Tectonics and Hotspot: The $3^{\text {rd }}$ dimension. Science, 256:1645-1651.

ASMUS H.E. \& PORTO R. (1980), Diferenças nos estágios iniciais da evolução da Margem continental brasileira: possíveis causas e implicações. In: SBG, Conre. Bras Geol., 31 Baln. Camboriú. Anais, v. 1, p. 225-239.

BLESS, M.J.M \& STREET, M. (1986). Late Devonian events around the old red contnent. Societé Geologique de Belgique, Liege.

CAETANO, L. C. (2000). Água Subterrânea no Município de Campos dos Goytacazes (RJ): Uma Opção para o Abastecimento. Dissertação de Mestrado. Campinas: UNICAMP.

CUNHA, P.R.C \& FRANÇA, A.B. (1994). Estudo das taxas de sedimentação das formações Terezinha e Rio do Rastro - Bacia do Paraná. B. Geoci. PETROBRÁS, 8 (2-4): 347-360. 
EIRAS, J.F., BECKER, C.R., SOUZA, E.M., GONZAGA, E.G., SILVA, J.G.E., DANIEL, L.M.F.M., MATSUDA, N.S. \& FEIJÓ, F.J. (1994). Bacia do Solimões. B. Geoci. PETROBRÁS, 8: 17-45.

FONSECA, M. J. C (1998). Mapa Geológico do estado do Rio de Janeiro. Brasília: DNPM.

GÓES, A.M.O., TRASSOS, W.A. \& NUNES, K.C. (1992). Projeto Parnaíba: Reavaliação da Bacia e Perspectivas Exploratórias. PETROBRÁS, Belém, 34p (Ret. Int.).

GRAHN, C.Y. \& PARIS, F. (1982). Age Correlations of The Trombetas Group, Amazonas Basin, Brazil. Rev. Micropaleontoligy, 35:197-209.

LEMOS, V.B. (1989). Bioestratigrafia do Paleozoico Superior das bacias do Amazonas e Solimões com base em conodontes. PETROBRÁS, Rio de Janeiro. Rel. Int.

MARTIN, L., SUGUIO, K., DOMINGUEZ, J.M.L. \& FLEXOR, J-M. (1997). Geologia do Quaternário costeiro do Litoral norte do Rio de Janeiro e do Espírito Santo. CPRM. Belo Horizonte. 112p.

MELLO, J.H.G. (1989). The Malvinokaffric realm in the Devonian of Brazil. In: N.J.Mcmillan, A.F. Embri, D.J. Glass (eds). Devonian of the world. CSPG, International Symposium on the Devonian System, 2, Calgary, 1989. Proceedings. Calgary, p. 669-703.

PETRI, S. \& FÚLFARO, V.J. (1983). Geologia do Brasil: Fanerozoico. Ed. USP, São Paulo, 631p.

PRESS, F.; GROTZINGER, J.; SIEVER, R. \& JORDAN, T. H. (2006). Para Entender a Terra. Tradução: MENEGAT, R. (coord.). 4a edição. Porto Alegre: BookMan.

RANGEL, H.D., MARTINS, F.A.L., ESTEVES, F.R. \& FEIJÓ, F.J. (1994). Bacia de Campos. B. Geoci. PETROBRÁS, 8 (1): 203-218.

SUGUIO, K. \& SALLUN, A. E. M. (2004). Geologia do Quaternário e Geologia Ambiental. In Mantesso-Neto, V. et. al. (Organizadores), Geologia do Continente Sul-Americano. (pp. 461 469). São Paulo: Beca.

VIEIRA, JR.N \& SOLIANI, JR. E. (1989). Um novo modelo genético - Evolutivo para o Maciço Granítico de Lavras do Sul, RS. ACTA GEOLOGICA Leopoldensia, 12 (29):143-160.

WICANDER, R. \& MONROE, J. S. (2009). Fundamentos de Geologia. São Paulo: Cengage Learning. http://www.stratigraphy.org/ICSchart/ChronostratChart2018-08.pdf, accessed in 23/11/2018.

https://www.google.com.br/Maps/place/Atafona,+S\%C3\%A3o+Jo\%C3\%A3o+da+Barra+-+RJ/@21.630301,-41.01889, accessed in 23/05/2018;

Google earth, accessed in 23/05/2018;

https://www.zazzle.com.br/relogio_grande_tempo//_geologico-256571964426580456, accessed in 21/05/2018;

https://www.youtube.com/watch?v=UwWWuttntio 